\title{
健診受診者における血圧に関する 意識調査及び家庭用血圧計の測定值について
}

$\begin{array}{ll}\text { 高橋比佐子 } & \text { 惣司八重子 } \\ \text { 木村 穣 } & \text { 西田 壽男 }\end{array}$

\section{目 的}

健診受診者の血圧に対する関心度を調査し，また同 時に家庭用血圧計の測定值についても従来よりの聴診 法と比較検討した。

\section{方 法}

当センター健診受診時に血圧に関するアンケート調 査を施行し, 血圧への関心度, 既往歴の有無, 家庭用 自動血圧計所有の有無, 家庭での測定方法等調查した。 また，従来よりの聴診法による血圧測定と同時に各種 家庭用自動血圧計 (上腕，手首，指用)による測定も施 行し，それぞれの測定值につき比較検討した。

\section{成 績}

アンケート記入回答者 (回収率： $73.4 \%$ )，平均年齢 $51.5 \pm 10.9$ 歳, 男性 349 例, 女性 312 例, 計 661 例に おいて，血圧に関して，“非常に関心あり”25.6\%，“ま あまあ” 50.6\%，“あまりなし”17\%，“なし”3\%，家 庭用血圧計所有率 $38 \%$, 測定回数 : 毎日 $22 \%$, 時及 $24 \%$ であった。家庭用血圧計所有率は 40 歳代以上にて 増加し, 60 歳代では半数以上の所有率を認めた。

当センター受診時に施行した血圧測定值では聴診
法：120.9 $\pm 21.9 / 75.9 \pm 12.4$, 家庭用上肢用 : $121.4 \pm$ $20.8 / 74.8 \pm 12$, 手首用 : $120.9 \pm 22.3 / 82.6 \pm 16.9$, 指 用 : $112.7 \pm 23.5 / 68.2 \pm 16.7 \mathrm{mmHg}$ と聴診法に比し 手首用最低血圧值において有意に高值を認め $(\mathrm{p}<$ 0.001), 指用最高, 最低血圧値において有意に低值を 認めた $(\mathrm{p}<0.001)$ 。その他の血圧值については聴診法 と差を認めず，また上肢用，手首用，指用ともに良好 な再現性を認めた。手首用最低血圧值の上昇の原因と して年齢, 肥満度が統計的(多変量因子分析：年齢, 肥 満度, 中性脂肪, コレステロール, HDL コレステロー ル, 尿酸, 耐糖能検査, 喫煙歴, 飲酒歴の独立因子よ り)に示された。

\section{結 語}

家庭用血圧計の再現性においては問題がなく，同一 人物の日常生活での血圧変動の管理には有用であると 思われた。アンケート調査より健診受診者での家庭用 血圧計の利用度, 測定値の信頼度においては不十分な ところがあり, 受診者の健康管理の一環として有効な 活用を勧めていく必要があると思われた。 